\title{
Profile of Cooperation Ability in Fourth Grade Students in Learning Entrepreneurship at Brecong 2 State Elementary School
}

\author{
Rizki Kurnianto, Siti Fatimah \\ Universitas Sebelas Maret \\ rizqikurnianto48@gmail.com
}

Article History
accepted 24/09/2019 approved 01/10/2019 published 01/12/2019

\begin{abstract}
The purpose of this study is to describe the profile of students' cooperative skills in entrepreneurial learning. This research approach is a qualitative approach and type of descriptive research. The subjects of this study were the fourth grade students of Brecong State Elementary School 2 Academic Year 2019/2020. The object of this study is the ability of students to collaborate in learning entrepreneurship. Data analysis was performed using descriptive techniques and existing data in the form of qualitative data from the observation sheets and student questionnaires, which were then described. The results showed that overall the ability of students to collaborate in learning entrepreneurship with "good" criteria with a percentage of $82.75 \%$ using the group discussion method. This can be seen from observations that show that students are able to participate in groups, interact face-to-face with their groups, accept responsibility, conduct deliberations, and help each other group members.
\end{abstract}

Keywords: cooperation, discussion, entrepreneurial learning

\begin{abstract}
Abstrak
Tujuan penelitian ini adalah untuk mendeskripsikan profil kemampuan kerja sama siswa dalam pembelajaran kewirausahaan. Desain penelitian adalah deskriptif sederhana. Subjek penelitian ini adalah siswa kelas IV SD Negeri 2 Brecong Tahun Ajaran 2019/2020. Objek penelitian ini adalah kemampuan kerjasama siswa pada pembelajaran Kewirausahaan Analisis data dilakukan dengan teknik deskriptif dan data-data yang ada berupa data kualitatif dari lembar observasi dan angket siswa,yang kemudian dideskripsikan. Hasil penelitian menunjukkan bahwa secara keseluruhan kemampuan kerjasama siswa dalam pembelajaran Kewirausahaan berkriteria "baik" dengan persentase $82,75 \%$ dengan metode diskusi kelompok. Hal ini dapat dilihat dari observasi yang menunjukkan bahwa siswa mampu berpartisipasi dalam kelompok, berinteraksi secara tatap muka dengan kelompoknya, menerima tanggung jawab, melakukan musyawarah, serta saling membantu sesama anggota kelompok.
\end{abstract}

Kata kunci: kerja sama, diskusi, pembelajaran kewirausahaan

Social, Humanities, and Education Studies (SHEs): Conference Series https://jurnal.uns.ac.id/shes

p-ISSN 2620-9284

e-ISSN 2620-9292 


\section{PENDAHULUAN}

Menurut Sagala (2014: 4) Pendidikan merupakan usaha sadar yang dilakukan oleh keluarga, masyarakat, serta pemerintah melalui pengajaran, bimbingan, atau latihan yang berlangsung di dalam maupun di luar sekolah. Menurut Mukminan (2014: 1) pada abad-21 sekarang kita memiliki tantangan untuk mampu menciptakan tata pendidikan yang bisa ikut menghasilkan sumber daya pemikir yang bisa ikut membangun tatanan sosial dan ekonomi sadar-pengetahuan sebagaimana layaknya warga dunia di abad-21. Tantangan Pendidikan pada abad 21 ini ditekankan bagaimana menciptakan pendidikan yang mampu menghasilkan sumber daya manusia yang mampu berpikir kritis, bersosialisasi, bekerja sama antar individu maupun kelompok, memiliki kemampuan komunikasi yang baik, serta memiliki jiwa kreativitas yang tinggi serta memiliki pemaham an akan perkembangan teknologi dan ilmu pengetahuan sehingga dapat menghadapi segala tuntutan dan persaingan di era globalisasi.

Pada dasarnya sebagai makhluk sosial manusia tidak dapat hidup sendiri tanpa bantuan dari orang lain. Oleh sebab itu dalam kehidupan bermasyarakat manusia membutuhkan kerja sama dengan orang lain dalam menjalankan kehidupannya. Begitu juga halnya dalam dunia Pendidikan. Dalam kegiatan pembelajaran siswa membutuhkan kerja sama dengan siswa lain dalam mencapai tujuan pembelajaran. Dengan melakukan kerja sama maka akan tercipta efektivitas dalam pembelajaran. Melalui kerja sama juga akan meningkatkan keaktifan siswa dalam kegiatan pembelajaran.

Kerjasama merupakan suatu usaha yang dilakukan bersama antara orang perorangan atau kelompok guna mencapai tujuan tertentu. Tidak akan ada keluarga, organisasi, sekolah, khususnya tidak akan ada proses pembelajaran di sekolah tanpa adanya kerja sama (Soekanto dalam Simamora, 2017).. Kemampuan kerja sama menurut Lie (dalam Yulianti, 2016) berguna bagi kehidupan siswa dimasa yang akan datang karena dapat membentuk pribadi yang unggul, khususnya di dalam dunia kerja dan kehidupan bermasyarakat. Keterampilan sosial dan kerjasama anak merupakan hal penting dan diperlukan anak untuk berinteraksi/bersosialisasi dengan keluarga, teman sebaya, dan lingkungan (Adistyasari, 2013: 54). Namun pada kenyataannya, masih banyak kejadian yang menunjukkan sikap kerja sama siswa belum terjalin dengan baik. Hal ini dapat dilihat dari berita yang dimuat di laman wartakota.tribunnews.com (2018) yang memberitakan sejumlah siswa sekolah dasar terlibat tawuran di Perumahan Pondok Sukmajaya Permai, Kota Depok. Dari fakta tersebut dapat terlihat bahwa masih rendahnya kerja sama antar pelajar. Untuk itu perlu ditanamkan sikap kerja sama sejak dini agar anak memiliki sikap kerja sama yang baik yang berguna bagi masa depannya.

Karakter kerja sama bisa ditanamkan, dilatih, dan dikembangkan melalui berbagai cara, salah satu wujudnya melalui kegiatan pembelajaran. Kerja sama dalam pembelajaran dapat dilakukan oleh dua siswa atau lebih yang saling berinteraksi, menggabungkan ide/pemikiran, tenaga, atau pendapat dalam waktu tertentu untuk mencapai tujuan pembelajaran sebagai kepentingan bersama. Menurut Rachmadyanti (2016), Pendidikan kewirausahaan merupakan pendidikan yang menerapkan prinsipprinsip dan metodologi kearah pembentukan kecakapan hidup (life skill) pada siswa melalui kurikulum yang dikembangkan di sekolah. Melalui pembelajaran kewirausahan dapat ditanamkan nilai-nilai kerja sama dalam pembelajaran.

Berdasarkan latar belakang di atas, peneliti tertarik untuk melakukan penelitian dengan judul "Profil Kemampuan Kerja Sama Siswa Kelas IV Dalam Pembelajaran Kewirausahaan di SD Negeri 2 Brecong". 


\section{METODE}

Pendekatan kualitatif merupakan pendekatan dari peneliatian ini dan jenis penelitian ini bersifat deskriptif. Subjek dalam penelitian ini adalah siswa kelas IV SD Negeri 2 Brecong tahun ajaran 2019/2020 yang berjumlah 35 siswa. Penelitian ini dilaksanakan pada tanggal 30 September 2019 di SD Negeri 2 Brecong yang beralamat di Desa Brecong RT 03 RW 05, Kecamatan Buluspesantren, Kabupaten. Kebumen. Data penelitian profil kemampuan kerja sama berupa data kualitatif yang diperoleh dari observasi dan angket siswa yang kemudian dideskripsikan. Kemampuan siswa dilihat berdasarkan kriteria sangat baik, baik, cukup, kurang baik dan sangat kurang baik. Teknik analisis data menggunakan Teknik Triangulasi dimana dalam teknik ini pengumpulan data bersifat penggabungan dari berbagai teknik dan menggunakan tiga langkah pengolahan data, yakni reduksi, menyajikan data, dan mengambil kesimpulan (Sugiyono, 2010: 330).

Data dianalisis dengan rumus deskriptif persentase menurut Ali (2013:01) sebagai berikut:

Skor $=\frac{\text { Jumlah Skor }}{\text { Skor Maksimal }} \times 100 \%$

Rumus ini bisa digunakan untuk mengkonversikan jawaban dari data yang telah dihitung. Adapun skalanya menurut Sudaryono, dkk. (2013) sebagai berikut:

Tabel 1. Kriteria kemampuan kerjasama siswa dalam Pembelajaran kewirausahaan

\begin{tabular}{cc}
\hline \multicolumn{2}{c}{ SKALA PERSENTASE DATA } \\
\hline PERSENTASE & KETERANGAN \\
$0-29 \%$ & Sangat kurang baik \\
$30-59 \%$ & Kurang baik \\
$60-79 \%$ & Cukup \\
$80-90 \%$ & Baik \\
$90-100 \%$ & Sangat baik
\end{tabular}

Selain itu, data yang lain dalam penelitian ini didapatkan dari observasi (pengamatan) langsung proses pembelajaran yang dipakai untuk mempertegas jawaban dari angket siswa yang kemudian dideskripsikan dalam pembahasan.

\section{HASIL DAN PEMBAHASAN}

Observasi kemampuan kerja sama siswa pada proses pembelajaran dilakukan selama kegiatan pembelajaran berlangsung. Berdasarkan hasil penelitian yang telah dilakukan di SD Negeri 2 Brecong diperoleh bahwa kemampuan kerja sama dalam pembelajaran kewirausahaan dinilai dari indikator Kontribusi setiap anggota kepada kelompok, tanggung jawab setiap anggota untuk menyelesaikan tugas, penyamaan pendapat seluruh anggota, serta sikap saling membantu sesama anggota kelompok. Data dalam penelitian dideskripsikan dalam diagram batang yang didapatkan dari angket dan observasi langsung proses pembelajaran di kelas.

Berdasarkan hasil penelitian yang telah dilakukan di SD Negeri 2 Brecong diperoleh data sebagai berikut: 
Tabel 2. Rata-rata Skor Kemampuan Kerja sama Siswa

\begin{tabular}{ccc}
\hline No & \multicolumn{1}{c}{ Indikator } & Persentase \\
\hline 1 & A. Kontribusi setiap anggota kepada kelompok & $81,71 \%$ \\
2 & B. Tanggung jawab setiap anggota untuk menyelesaikan tugas. & $82,85 \%$ \\
3 & C. Penyamaan pendapat seluruh anggota & $83,75 \%$ \\
4 & D. Sikap saling membantu sesama anggota kelompok & $83,09 \%$ \\
& Persentase keseluruhan & $82,75 \%$ \\
\hline
\end{tabular}

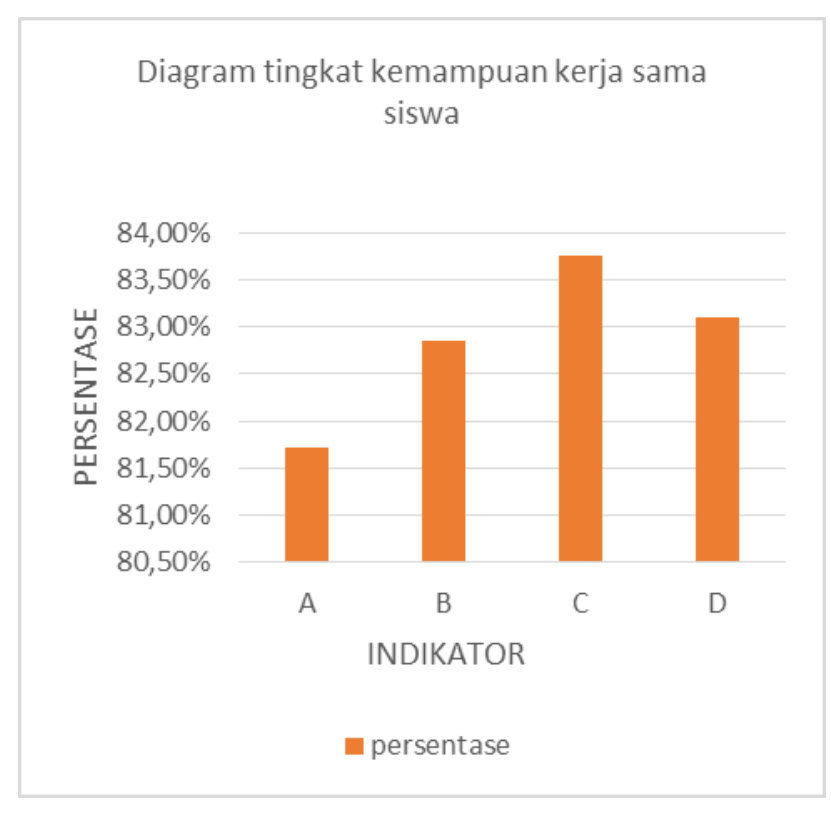

Gambar 1. Diagram tingkat kemampuan kerja sama siswa

Ket: $\boldsymbol{A}=$ Kontribusi setiap anggota kepada kelompok; $\boldsymbol{B}=$ Tanggng jawab setiap anggota untuk menyelesaikan tugas.; $\boldsymbol{C}=$ penyamaan pendapat seluruh anggota,; $\boldsymbol{D}=$ sikap saling membantu sesama anggota kelompok;

Dari perhitungan data menggunakan angket pada indikator pertama yaitu kontribusi setiap anggota kelompok diperoleh persentase sebesar $81,71 \%$. Hal ini selaras dengan pengamatan penulis yang dilaksanakan selama proses pembelajaran kewirausahaan terlihat masing-masing siswa memiliki kontribusi dan berperan aktif ketika kegiatan kelompok sedang dilaksanakan. Hal ini menunjukkan bahwa kemampuan kerja sama siswa pada indikator kontribusi setiap anggota kelompok berada pada kriteria baik.

Pada indikator kedua yaitu tanggung jawab setiap anggota untuk menyelesaikan tugas dari perhitungan data menggunakan angket diperoleh persentase sebesar $82,85 \%$. Hal ini menunjukkan bahwa kemampuan kerja sama siswa berada pada kriteria baik. Dari hasil pengamatan yang penulis lakukan selama proses pembelajaran siswa memberikan usulan/pendapat untuk membantu menyelesaikan tugas dalam kelompok, siswa mengetahui permasalahan yang dikerjakan kelompok, dan siswa melaksanakan tugas yang telah dibagi dalam kelompok kemudian meminta pertimbangan teman satu kelompok. Ketika kegiatan kelompok sedang dilaksanakan, siswa fokus dengan kelompok sendiri tidak berjalan-jaln ke kelompok yang lain.

Pada indikator ketiga yaitu penyamaan pendapat seluruh anggota dari perhitungan data menggunakan angket diperoleh persentase sebesar $83,75 \%$. Dari hasil pengamatan penulis, selama proses pembelajaran siswa mampu memberikan 
tanggapan terhadap pendapat teman, tidak dengan pertimbangan. Siswa ikut serta berpartisipasi dan antusias dalam penyamaan pendapat. Hal ini menunjukkan bahwa kemampuan kerja sama siswa berkriteria baik untuk indicator penyamaan pendapat seluruh anggota.

Pada indikator keempat yaitu sikap saling membantu sesama anggota kelompok dari perhitungan data menggunakan angket diperoleh persentase sebesar 83,09\%. Dari hasil pengamatan penulis dapat diketahui bahwa selama proses pembelajaran siswa kompak saling memberi bantuan sesama anggota kelompok dan siswa saling menghargai antar sesama anggota kelompok maupun dengan kelompok yang lain. Hal ini menunjukkan bahwa secara umum kemampuan kerja sama siswa berkriteria baik untuk indicator kerja sama sikap saling membantu sesama anggota kelompok. Berdasarkan diagram tingkat kemampuan kerja sama siswa kelas IV diatas dapat diketahui bahwa tingkat persentase tertinggi yaitu pada indicator $\mathrm{C}$ yaitu penyamaan pendapat seluruh anggota.

Berdasarkan perhitungan data angket dan observasi pengamatan langsung dikelas dapat dilihat bahwa kemampuan kerja sama siswa kelas IV dalam pembelajaran kewirausahaan secara umum berkriteria baik. Pada saat pelaksanaan penelitian dilangsungkan kegiatan kelompok untuk membuat produk gelang dan kalung dari manik-manik. Siswa dibentuk kelompok dengan masing-masing kelompok memiliki tugas untuk membuat 1 karya gelang atau kalung dari manik-manik. Pembuatan karya dilakukan dengan teknik meronce. Alat dan bahan disediakan oleh guru kelas. Guru kelas menampilkan contoh karya yang sudah jadi dan siswa diminta untuk membuat karya sesuai kreasi sendiri. Saat pelaksanaan kegiatan kelompok secara keseluruhan dari 4 indikator sikap kerja sama siswa dalam kelompok baik dengan persentase 82,75 $\%$.

Pola kerja sama yang terbentuk dari kegiatan kelompok yang dilaksanakan yaitu kerja sama kontrak. Sesuai dengan penelitian Simamora,dkk (2017) menjelaskan bahwa kerja sama kontrak ditandai dengan yang pertama, bertanggung jawab dengan tugas yang diberikan. Hal ini selaras dengan hasil observasi saat kegiatan kelompok membuat gelang dan kalung dari manik-manik, masing masing anak dalam kelompok serius dalam membuat karya yang ditugaskan oleh guru. Ciri kerja sama yang kedua yakni setiap anggota kelompok tetap berada dalam kelompoknya saat kegiatan kelompok berlangsung. Hal ini juga sesuai dengan pengamatan yang penulis lakukan dikelas saat kegiatan kerja kelompok membuat karya gelang dan kalung dari manikmanik, siswa focus dengan kelompok sendiri, tidak jalan-jalan ke kelompok lain dan tidak membuat keributan di kelas. Ciri yang ketiga adalah menyelesaikan tugas tepat waktu. Saat pengamatan dilakukan, siswa dalam membuat tugas kelompok memanfaatkan waktu yang telah diberikan untuk menyelesaikan tugas sehingga siswa menyelesaikan tugas dengan tepat waktu. Siswa bekerja secara efektif dan efisien dengan memanfaatkan waktu yang ada.

\section{SIMPULAN}

Dari hasil penelitian dan pembahasan diatas, dapat disimpulkan bahwa kemampuan kerja sama siswa kelas IV dalam pembelajaran kewirausahaan di SD Negeri 2 Brecong telah berada dalam kriteria "baik" dilihat dari persentase yaitu 82,75 $\%$. Hasil ini didapat dari hasil pengisian angket siswa dan observasi kegiatan pembelajaran yang menunjukkan siswa mampu ikut serta/berkontribusi dalam sama dalam kelompok, memiliki tanggung jawab untuk menyelesaikan tugas dalam kelompok, dan sikap saling membantu menghargai sesama anggota kelompok. Pola kerja sama yang terbentuk yaitu kerja sama kontrak. 
DAFTAR PUSTAKA

Adistyasari, R. (2013). Meningkatkan Keterampilan Sosial dan Kerjasama Anak Dalam Bermain Angin Puyuh, Skripsi Universitas Negeri Semarang.

Ali, M. 2013. Prosedur dan Strategi Penelitian Pendidikan. Bandung: Angkasa.

Malau, B. S. L. (2018). Siswa Sekolah Dasar Tawuran Diamankan Warga di Depok. Diakses dari https://wartakota.tribunnews.com/2018/08/04/siswa-sekolahdasar-tawuran-diamankan-warga-di-depok pada 14 September 2019

Mukminan. (2014). Tantangan Pendidikan Di Abad 21. Yogyakarta: Universitas Negeri Yogyakarta: Diakses pada tanggal 21 September 2019

Rachmadyanti, Putri dan Vicky Dwi Wicaksono. (2016). Pendidikan Kewirausahaan Bagi Anak Usia Sekolah Dasar. Prosiding Seminar Nasional Inovasi Pendidikan Diunduh dari http://jurnal.fkip.uns.ac.id/index.php/snip/article/view/8960/6521 Pada tanggal 17 September 2019

Sagala, S. (2014). Konsep dan Makna Pembelajaran. Bandung: Alfabeta

Simamora, D. M. (2017). Profil Kemampuan Kerjasama Siswa Dalam Pembelajaran IPA. Jurnal Pendidikan Biologi Vol. 5, No.2. Diunduh dari http://jurnal.fkip.unila.ac.id/index.php/JBT/article/view pada tanggal 13 Desember 2019

Sudaryono, dkk. (2013). Pengembangan Instrumen Penelitian Pendidikan. Yogyakarta: Graha IImu.

Yulianti, S. D. dkk. (2016). PENDIDIKAN KARAKTER KERJA SAMA DALAM PEMBELAJARAN SISWA SEKOLAH DASAR PADA KURIKULUM 2013. Jurnal Teori dan Praksis Pembelajaran IPS Vol. 1, No. 1, 419-437. Universitas Negeri Malang 